\title{
Bor man tillate at norske statsborgere benytter seg av surrogati i India?
}

\author{
Annelin Haukeland ${ }^{1}$, Liv Cathrine Heggebø ${ }^{2}$ og Kristine Bærøe ${ }^{3}$ \\ ${ }^{1}$ Universitetet i Bergen \\ any_h@hotmail.com \\ ${ }^{2}$ Universitetet i Bergen \\ livchegg@online.no \\ ${ }^{3}$ Institutt for global helse og samfunnsmedisin, Universitetet i Bergen \\ kristine.baroe@igs.uib.no
}

I Norge er ikke surrogati tillatt, og myndighetene fraråder norske statsborgere å benytte seg av surrogati $i$ utlandet. I denne artikkelen fokuserer vi på kommersiell gestational surrogati og stiller spørsmålet: Bør man tillate at norske statsborgere benytter seg av surrogati $i$ India? De etiske problemstillingene rundt surrogati er mange og sammensatte og blir spesielt utfordrende når tjenesten tilbys $i$ et land med store kulturelle og økonomiske forskjeller både internt og i forhold til Norge. Vi baserer analysen og drøftingen av dette etisk utfordrende spørsmålet på Beauchamps og Childress sin veletablerte metodiske tilnorming innen biomedisinsk etikk. Vi anvender de fire allmennmoralske prinsipper: respekt for autonomi, velgjørenhet, ikke-skade og rettferdighet på sakskomplekset for å synliggjøre spenningene involvert $i$ dette etiske dilemmaet. Med full bevissthet om at det ikke finnes noen lettvinte og omkostningsfrie løsninger på dilemmaer generelt og dette spesielt, konkluderer vi med at interessene til de berørte parter, og spesielt surrogatmødrenes, kan bli bedre ivaretatt om surrogati tillates under omfattende reguleringer. Dersom man velger å gjøre praksisen illegal, vil man også miste mulighetene til å påvirke prosessen og sikre rettighetene til de involverte partene.

Nøkkelord: surrogati, Norge-India, utnyttelse, autonomi, regulering av prosessen

\section{English summary: Should Norwegian citizens be permitted to use surrogacy in India?}

Surrogacy is not permitted in Norway, and the government strongly advises against Norwegian citizens travelling abroad to have children through the use of the surrogacy industry. In this article, we focus on commercial gestational surrogacy and debate the question: Should Norwegian citizens be permitted to use surrogacy in India? The ethical concerns regarding surrogacy are complex and are especially challenging when the service is offered in a country with big cultural and economic differences both internal and in comparison to Norway. We base our analysis of this ethical, challenging question on Beauchamp's and Childress's well-established approach within biomedical ethics. We apply the four principles of respect 
for autonomy, beneficence, nonmaleficence and justice to shed light on the conflicts of interests in this ethical dilemma. With full awareness that there are no simple and correct solutions to dilemmas in general and on this issue, especially, our conclusion is that the interests of the involved parties, and especially those of the surrogate mothers, might be better attended to if surrogacy is allowed with extensive regulations. If this practice is made illegal, the opportunity to influence the process and secure the rights of the involved parties is lost.

Keywords: surrogacy, Norway-India, exploitation, autonomy, regulation of the process

\section{Innledning}

«Surrogati» beskriver generelt en form for reproduksjon der en kvinne gjennomfører et svangerskap på vegne av andre. Surrogati er et svært omstridt tema i Norge. Det er mange som har sterke meninger om hvorvidt det er akseptabelt å få barn ved hjelp av surrogati. Barnelege og leder av rådet for legeetikk i Legeforeningen Trond Markestad sammenligner surrogati med salg av organer (Sundby 2010). Han hevder det er en helsemessig risiko vi ikke kan godta, selv om de som velger å selge, får en stor økonomisk gevinst. Han er redd det vil føre til helseimperialisme, der de med kjøpekraft kan betale for helsegevinster som samtidig innebærer at andre vil utsette seg for en stor risiko. Blant tilhengerne av surrogati finner vi leder for Klinisk psykisk helse og avhengighet ved Oslo universitetssykehus, Øystein Mæland. Han har selv benyttet seg av surrogati og har uttalt: «Møtet med både eggdonor og surrogat overbeviste oss om at det finnes ressurssterke og oppegående kvinner som på selvstendig grunnlag bestemmer seg for å ville bidra til at andre mennesker får oppfylt sitt sterke ønske om å få barn.» (Sundby 2010: 104). Dette er bare to av svært mange innspill i en meget opphetet debatt. Uenighetene kan relateres til at sakskomplekset representerer et reelt etisk dilemma. Som eksemplene overfor viser, vektlegger de fremsatte perspektivene forskjellige normative prinsipper: På den ene siden veier den moralske plikten om å ikke tilrettelegge for utnyttelse av vanskeligstilte tyngst. På den annen side er vekten lagt på de positive konsekvensene surrogati kan ha for surrogatmor og de intenderte foreldrene. I denne artikkelen ønsker vi å bidra til en ytterligere nyansering av denne debatten gjennom en analytisk fremstilling av ulike etiske sider ved surrogati og en systematisk drøfting av de etiske spenningene som vil være involvert.

Vi har valgt å avgrense diskusjonen ved å fokusere på norske statsborgere som ønsker barn, og indiske surrogatmødre. Det er store kulturelle og økonomiske forskjeller mellom de landene som tilbyr surrogati, og dilemmaene knyttet til surrogati, blir dermed også ulike. Indiske surrogatmødre har vært mye drøftet i norske medier den siste tiden, og de er et populært valg for norske par som ønsker å benytte seg av surrogati i utlandet. Derfor har vi valgt å begrense oss til situasjonen i India. Når vi skal diskutere surrogati, er det også nødvendig å definere hvilke former for surrogati vi snakker om. I denne artikkelen fokuserer vi på såkalt gestational surrogati, det vil si tilfeller av surrogati der det blir innsatt et ferdig befruktet embryo i surrogatmor, som dermed ikke vil være genetisk relatert til barnet. Vi er også i denne sammenhengen opptatt av kommersiell surrogati, der kvin- 
nen blir betalt for å gjennomgå svangerskapet, og vi diskuterer spesielt denne formen for surrogati slik det praktiseres i India (Ramskold \& Posner 2013).

Artikkelen er organisert som følger. Vi starter med å gi en oversikt over hvordan situasjonen rundt surrogati er i henholdsvis Norge og India basert på tilgjengelig litteratur. Deretter følger en analysedel der vi tar for oss fire veletablerte etiske prinsipper fra den biomedisinske fagdiskursen og viser hvordan disse kan belyse de etiske problemstillingene rundt den aktuelle surrogatipraksisen. Mot denne bakgrunnen drøfter vi så ulike etiske spenninger man må forholde seg til når man på politisk nivå tar stilling til om dette er en praksis man skal legge til rette for.

\section{Surrogati i Norge}

Bruk av surrogatmødre er et mye omdiskutert tema i Norge, og det etterlyses en tydelig markering fra statens side med hensyn til hvilke prinsipper som skal regulere praksis. Surrogati er ikke tillatt i Norge på den måten at det er ikke er lov å sette inn eggceller som ikke er kvinnes egne (Regjeringen 2013). Avtaler om surrogati er etter barneloven ikke bindende i Norge. I mai 2013 kom regjeringen med en ny uttalelse der de understreker at surrogati er ulovlig i Norge. Selv om det ikke er forbud mot å benytte seg av surrogati i utlandet, fraråder styresmaktene at norske statsborgere benytter seg av denne muligheten (Regjeringen 2013). I det samme skrivet pekes det også på at for dem som vurderer surrogati i utlandet, er det ingen garanti for at barnet vil få norsk statsborgerskap. Barneloven $\$ 2$ sier at den kvinnen som føder barnet, er barnets mor, selv om kvinnen ikke har felles gener med det fødte barnet (Barne- likestillings- og inkluderingsdepartementet 1981). Hvem som er barnets far, bestemmes enten ut ifra en gentest, eller ved at den moren er gift med, regnes som far. Dersom far har felles gener med barnet, og farskapet blir godkjent, må den andre forelderen eventuelt søke om stebarnsadopsjon. Hvis ingen av de intenderte foreldrene har felles gener med barnet, må det søkes om adopsjon (Regjeringen 2013). Adopsjonsloven sier at når norske statsborgere skal adoptere fra et annet land, skal dette være forhåndsgodkjent av den norske stat (Barne- likestillings- og inkluderingsdepartementet 1986). India vil på sin side ikke gi barnet indisk statsborgerskap siden det aldri har vært meningen fra deres side at barnet skulle bli i India (Syse 2012). Barnet har heller ikke fått norsk statsborgerskap, ettersom kvinnen som føder barnet, er indisk. Barnet har derfor ifølge norsk lov ikke noe grunnlag til å få norsk statsborgerskap. (Syse 2012) Det finnes for tiden et midlertidig regelverk som skal hindre at barnet blir statsløst, men dette skal oppheves 31. desember 2015 (Regjeringen 2013).

I 2012 ble det i Norge søkt om 37 stebarnadopsjoner der barnet er blitt født av en surrogatmor (Dommerud 2013). I hvor mange av disse tilfellene det er snakk om tvillinger, er ikke kjent, heller ikke hvilket land barnet er født i (Dommerud 2013). Ifølge Agderposten opplyser den indiske ambassade at det kom 36 surrogatbarn fra India til Norge i 2012 (Prestegård 2013). Det er meget mulig at det er mange barn som er født gjennom surrogati og ført inn i Norge uten at det er blitt offisielt registrert, Surrogatiforeningen i Norge hevder at det kan dreie seg om rundt 200 barn (Syse 2012). 
De siste årene har barnløsheten i Norge vært jevnt stigende. Hos heterofile par er det omtrent 10 prosent som opplever ufrivillig barnløshet (Nesheim 2009). Hos både menn og kvinner har alderen for når de får sitt første barn, steget med rundt tre år fra 1987 til 2011 (Statistisk sentralbyrå 2012). Fertiliteten til kvinner synker med alderen, så ved å vente lenger med å få barn, kan det bli vanskeligere å oppnå et suksessfullt svangerskap (Nesheim 2009).

Forskning har gjort det mulig å bli foreldre på utradisjonelle måter, som ved eggdonasjon og sæddonasjon, «in vitro fertilisering» ('utenfor kroppen') og ved hjelp av surrogati. Samfunnets samlivsformer har også endret seg markant. Mange enslige norske kvinner reiser for eksempel til Danmark for å få sæddonasjon eller eggdonasjon, og bruk av surrogatmødre i utlandet har økt. India er et populært valg ved bruk av surrogati på grunn av at prisnivået er lavere her enn i mange andre land (Aanensen \& Staude 2010). Å benytte en surrogatmor i USA har en prislapp på rundt 1 million NOK, mens i India vil prosessen komme på rundt en tredjedel av beløpet.

\section{Surrogati i India}

Republikken India hadde i 2012 et folketall på over 1,2 milliarder (Store Norske Leksikon 2012a). Det er et land som er preget av store ulikheter både økonomisk og kulturelt. Det antas at i 2012 levde 28 prosent av befolkningen under fattigdomsgrensen (Store Norske Leksikon 2012a). Det betyr at over 300 millioner mennesker i India lever under det inntektsnivået som trengs for å dekke basale behov som for eksempel mat, drikke og husly. Ifølge UNESCO var ca. 42 prosent av befolkningen analfabeter i 2000 (Store Norske Leksikon 2012b). Men det er store regionale forskjeller og dessuten forskjeller mellom kjønnene, ettersom to tredjedeler av analfabetene er kvinner. Det illustrerer at situasjonen og problemstillingene rundt surrogati i India er sammensatt. Mange kvinner er fattige og analfabeter, noe som gjør at det kan være vanskelig å være sikker på at de er fri til å ta opplyste valg og ikke blir tvunget inn i surrogati. Samtidig er surrogati blitt en enorm industri i India. Det stimulerer den nasjonale økonomien og har skaffet mange arbeidsplasser i både servicesektoren og helsesektoren. Surrogati-industrien estimeres til å være verdt mellom 500 millioner og 2,3 milliarder USD i 2013 (Deonandan et al. 2012).

Surrogati i India reguleres av The Assisted Reproductive Technologies (Regulation) Bill- 2010. Denne loven regulerer prosedyrene for registrering og kontroll av slike klinikker. Den gjør det også klart hvilke plikter klinikkene har. Blant annet er kjønnsseleksjon strengt forbudt, og klinikkene plikter å dokumentere alt som skjer på klinikken (Government of India 2010, 2013). Dessuten er det kommet nye reguleringer av surrogati-industrien. 9 juli 2012 kom det nye retningslinjer fra Government of India Ministry of Home Affairs som gjør det klart at par som har til hensikt å benytte seg av surrogati i India, må søke om medisinsk visum for å oppholde seg lovlig i landet (Government of India 2013). For å få innvilget et slikt visum er det flere kriterier som må oppfylles. Ett av kravene er at paret må bestå av en mann og en kvinne som har vært gift i minst to år. Det fører til at det ikke lenger vil være mulig for utenlandske, homofile par eller enslige å benytte seg av 
surrogati i India. Paret må også ha et skriv fra utenriksministeren eller fra ambassaden til landet de er fra, hvor det bekreftes at landet anerkjenner surrogati, at paret anerkjennes som biologiske foreldrene til barnet, og at barnet vil få statsborgerskap i parets hjemland. Det fører til at par fra land som ikke anerkjenner surrogati, ikke lenger kan benytte seg av surrogati i India. Paret må også signere på at de vil oppfylle foreldreansvaret overfor barnet/barna som fødes gjennom surrogati. Dette sikrer at de intenderte foreldrene har ansvar for barna uansett hvilke situasjoner som skulle oppstå, for eksempel dersom barnet skulle vise seg å være sykt. Et annet krav er at surrogatien skal finne sted på en av ARTklinikkene (Assisted Reproductive Technology) som er godkjente av Indian Council of Medical Reasearch (ICMR). Det kreves også at paret inngår en kontrakt med surrogatmoren (Government of India 2013). Disse kontraktene lages som regel av ART-klinikken som paret benytter seg av. Slik situasjonen i India er nå, reguleres surrogatmorens plikter og rettigheter først og fremst av kontrakten hun har med klinikken. I det følgende refererer vi til en kontrakt fra Newlife India Surrogacy som et eksempel på en slik kontrakt (Newlife India 2012). Firmaet har en rekke krav som surrogatmoren må innfri. Dersom hun bryter noen av kriteriene i kontrakten, kan hun pålegges å betale en bot på 5000 rupies til firmaet innen ti dager. Surrogatmoren har rett til å få utbetalt 350000 rupies, altså ca. 35000 NOK for prosessen innen tre dager etter fødselen. Dette høres kanskje ikke så mye ut, men for kvinnen kan dette tilsvare 15 årslønner (Ramskold \& Posner, 2013). Ettersom kontraktene ikke reguleres av det offentlige, er det rimelig å tro at de kan variere betydelig fra firma til firma.

\section{Fire prinsipper for biomedisinsk etikk}

For å analysere de etiske sidene ved å la norske par få benytte surrogati i India, støtter vi oss på fire, veletablerte etiske prinsipper i biomedisinsk etikk. De samme prinsippene er nylig anvendt i en diskusjon om hvorvidt surrogati bør underlegges internasjonale, legale reguleringer (Ramskold \& Posner 2013). Denne artikkelen inspirerte oss til å gjøre bruk av det samme analytiske verktøyet og foreta en lignende, men allikevel uavhengig analyse av den spesifikke problemstillingen om norske par bør tillates å benytte surrogati i India. Prinsippene er beskrevet $\mathrm{i}$ «Principles of Biomedical Ethics» av Beauchamp og Childress (2013) og omfatter prinsipper om respekt for autonomi, velgjørenhet, ikke-skade og rettferdighet. Disse fire prinsippene er ikke utledet fra en distinkt moralteori, de er snarere basert på et empirisk-pragmatisk fundament, Dette er moralske prinsipper amerikanske etikk-komitémedlemmer syntes å kunne enes over som relevante, generelle rettledende prinsipper for medisinsk-etisk komitéarbeid, til tross for medlemmenes ulike religiøse og politiske holdninger. Prinsippene ansees av Beauchamp og Childress som et uttrykk for en allmennmoral. Denne prinsippbaserte tilnærmingen til normative problemstillinger har ikke fått stå uimotsagt. (Clouser \& Gert 1990). Til tross for dette, samt innsigelser om at prinsippene i utgangspunktet er spesielt tilpasset amerikanske forhold, har prinsippene over tid vunnet bred aksept som rettesnorer for medisinsketiske tilnærminger også utenfor USAs grenser. De er presentert som ikke-absolutte normer. Det betyr at avveiin- 
ger mellom hvilket prinsipp som skal veie tyngst, må foretas i den enkelte kontekst. Ettersom prinsippene antas å være utrykk for en allmennmoral, er heller ikke prinsippenes relevans utelukkende knyttet til en biomedisinsk kontekst. Prinsippene vil være relevante i alle slags situasjoner der allmenne, menneskelige hensyn står på spill. Det faktum at rammeverket består av flere, det vil si fire, prinsipper, bidrar også til at saksområder systematisk kan tilnærmes fra flere sider. Det øker sjansen for at det som fremstår som relevante hensyn for hver enkelt involverte parts ståsted, kan bli fanget opp, beskrevet og drøftet på en adekvat måte. Alle disse sidene ved dette etiske rammeverket gjør prinsippene også til nyttige, analytiske redskaper for sortering av ulike etiske sider ved surrogati i en norsk-indisk kontekst.

\section{Drofting av de fire etiske prinsippene i tilknytning til surrogati}

I det følgende vil vi anvende de fire etiske prinsippene for å klargjøre de etiske utfordringene knyttet til surrogati. En anvendelse av prinsippene forutsetter imidlertid at vi kan knytte de ulike prinsippene til aktørene de angår. Disse er surrogatmor, intenderte foreldre, barnet som fødes av surrogatmor, klinikkene, involvert helsepersonell og det indiske og det norske samfunn. I den følgende analysen beskriver vi ulike kombinasjoner av prinsipper og berørte parter. Listen over mulige kombinasjoner er ikke nødvendigvis uttømmende, den er basert på tilgjengelig litteratur og egenhendig refleksjon.

\section{Respekt for autonomi og surrogati}

Ordet autonomi stammer opprinnelig fra gresk og betyr 'selvstyre'. I medisinsk sammenheng brukes det først og fremst om selvstyre på individnivå. Respekt for autonomiprinsippet handler dermed om å forhindre at retten til å bestemme over seg selv blir truet. I henhold til trebetingelsesteorien fra «Principles of Biomedical Ethics» vil det å handle autonomt si at man handler med i) intensjon, ii) forståelse og iii) uten kontrollerende impulser som bestemmer hvilke valg man skal ta. Med hensyn til det tredje punktet, dvs. friheten til å handle uten kontrollerende impulser, skiller man mellom interne og eksterne påvirkninger. Interne handler om personens eget tanke- og følelsesliv, mens eksterne kan komme fra personer man har kontakt med, eller i form av sosiale og politiske reguleringer (Beauchamp \& Childress 2013: 101-149).

Vi vil nå drøfte om alle disse faktorene kan forventes å være til stede hos potensielle surrogatmødre i India og hos de intenderte foreldrene. Dette blir selvsagt en generalisering av potensielle surrogatmødre og intenderte foreldre på gruppenivå og vil ikke være gyldig for enkeltindivider i alle situasjoner.

Det er liten tvil om at de indiske kvinnene har intensjoner om å gå inn i surrogatien. Det at en handling er intensjonell, betyr imidlertid ikke nødvendigvis at det er noe man er positivt motivert for å gjøre. Det betyr bare at man er bevisst på valget man tar (Beauchamp \& Childress 2013: 101-149). Hvorvidt kvinnene har en tilstrekkelig forståelse for konsekvensene av valget de tar, er det nok langt større usikkerhet om. Å gjennomføre et 
surrogatisvangerskap kan være skadelig i både fysisk, mental og sosial forstand (Deonandan et al. 2012). Det kan være store mentale påvirkninger av å gjennomgå et svangerskap, særlig når kvinnen skal gi fra seg barnet etter fødselen. Dessuten skal man ikke glemme at surrogati ikke alltid er godtatt av samfunnet. Det er mulig at surrogatmødrene blir utestengt sosialt av familie, venner og samfunnet rundt henne. Disse risikoene bør også legges frem for surrogatmoren for at hun skal kunne ta et autonomt valg om å være surrogatmor (Deonandan et al. 2012).

Når det gjelder frihet fra påvirkning, representerer dette et nokså komplekst kriterium ettersom det innbefatter både interne og eksterne påvirkninger. Et eksempel på en intern påvirkning kan være at kvinnen ikke føler hun har noe annet alternativ fordi hun virkelig trenger pengene hun tjener på å bære frem andres barn. Når det gjelder eksterne påvirkninger, kan kvinnen føle seg presset av representanter fra klinikken som oppleves som autoritære. Disse representantene er høyere utdannet, har et økonomisk overtak og en sterkere sosial stilling (Deonandan et al. 2012). Kvinnene kan også bli presset inn i situasjonen av familien sin (Taylor 2011). India er et land med patriarkalsk familiestruktur der mannen ofte bestemmer hjemme.

Samtidig må man også huske på at prinsippet om å respektere autonomi ikke skal kreve et ideal som er utenfor rekkevidde for normale, kompetente mennesker. Det er urealistisk å kreve full forståelse av alle aspekter ved surrogatiprosessen og utelukke enhver form for påvirkning. Det kreves bare en viss grad av forstålse og en viss grad av frihet fra påvirkning for at et valg skal regnes som autonomt. Uansett, det forblir allikevel en utfordring å skulle fastsette akkurat hvor mye som skal kreves, og hvordan man skal kunne teste at kvinnene oppfyller kravene til å foreta et autonomt valg.

At det skal tas et autonomt valg, gjelder også de intenderte foreldrene. Her er det ingen problemer rundt intensjon. Det kan derimot være et problem at de har manglende forståelse for konsekvensene deres eget valg kan ha for surrogatmoren. De intenderte foreldrene er sannsynligvis i mindre grad utsatt for ekstern påvirkning. Likevel skal man være observante på at de også er i en sårbar situasjon. Trendene i samfunnet gjør det vanskeligere å være barnløs; barn blir gjerne sett som en del av selvrealisering. Det å være barnløs vil for mange oppleves som emosjonelt utfordrende (Løvaas 1998). Derfor blir det viktig å forsikre seg om at også de intenderte foreldrene er i stand til å ta et autonomt valg.

Eksterne påvirkninger i form av politiske reguleringer kan begrense friheten til å foreta autonome valg. Samfunnet har mulighet til å ta overordnet valg om at surrogati ikke er akseptabelt, og dermed utelukke alle kvinner fra surrogati. Som beskrevet ovenfor har India valgt å regulere surrogatiprosessene med lovgivning - i motsetning til Norge der surrogati ikke er tillatt nasjonalt, og myndighetene fraråder norske statsborgere å benytte seg av tilbud i utlandet.

\section{Velgjorenhet og surrogati}

Prinsippet om velgjørenhet, det vil si å gjøre godt, beskriver en plikt om å bidra til andres velferd. Plikten innebærer en aktiv handling, det er ikke nok å bare passivt unngå å skade andre. Det er ikke snakk om handlinger som krever store offer, ekstrem grad av altruisme 
eller handlinger som utsetter en selv for stor risiko. For at dette skal være en plikt, er det visse krav som må oppfylles: Personen som man gjør godt mot, må ha helseproblemer eller kunne risikere store tap, og det man gjør, må være nødvendig og redusere risikoen personen står overfor (Beauchamp \& Childress 2013: 202-248).

For intenderte foreldrene kan surrogati oppfylle en livslang drøm. I mange tilfeller kan nok ønsket om å gjøre noe godt for andre være en del av motivasjonen for kvinnene som velger å bli surrogatmødre. I det minste er det noe som de fleste ser på som en av de positive sidene ved surrogati. Det er derimot diskutabelt om prinsippene for velgjørenhet er oppfylt i denne situasjonen. Kvinnen utsetter seg for risiko, og det er høyst diskutabelt om de intenderte foreldrene er i en stor nok risiko for tap eller har så store helseproblemer at prinsippet om andres plikt til å gjøre godt skal være gjeldende. Likevel er det viktig å huske på at det kan være mentalt og sosialt vanskelig å være barnløs. Og forskning viser at flertallet av dem som ikke har barn, dør tidligere og er mer plaget med psykiske problemer (Hammer 2012).

I prinsippet har klinikkene og helsepersonell en plikt til å bidra til alle pasientenes velferd, inklusive surrogatmødrene. Velgjørenhet overfor kvinnen fra surrogatiklinikkens side vil først og fremst dreie seg om at hun får en økonomisk gevinst. Det er ikke usannsynlig at dersom kvinnen bidrar med vesentlig inntekt til en vanskelig familieøkonomi, vil dette kunne styrke hennes sosiale rolle og bidra til et bedre kvinnesyn i India. Helsepersonell skal imidlertid først og fremst fremme helse, og den økonomiske delen med hensyn til velgjørenhet er derfor underordnet. Velgjørenhet handler i den forstand om at surrogatmor i best mulig grad skal beskyttes mot risiko under svangerskapet. Et interessant aspekt når det gjelder velgjørenhet, er om helsepersonell bør regne det å $i k k e$ bidra i surrogatiprosessen som det mest velgjørende overfor kvinnen, ettersom det å bidra vil medvirke til å utsette kvinnen for de risikoene et svangerskap vil innebære.

Velgjørenhet kan også knyttes til surrogati på et samfunnsnivå. Samfunnet har en viss ikke-instrumentalistisk plikt til å ivareta innbyggernes helse og beskytte dem fra unødvendig risiko. På den andre siden vil den indiske stat ha økonomisk nytte av at surrogati blir legalisert. Surrogati er en stor industri i India, og den kan sysselsette mennesker som ellers kunne vært arbeidsløse (Shetty 2012).

\section{Ikke-skade og surrogati}

Plikten om å ikke skade andre skiller seg fra plikten å hjelpe andre. Å ikke skade andre innebærer først å fremst å ha som intensjon å unngå handlinger som har skadelige konsekvenser, mens det å hjelpe andre krever handlinger som å forebygge, fjerne eller fremme et gode. Plikten om å ikke skade vil som regel overstyre plikten om å hjelpe. Ikkeskade-prinsippet innebærer også at man skal unngå å utsette andre for risiko for skade. For eksempel skal ikke helsepersonell forsømme pasienter ved ikke å gjøre jobben man er satt til (Beauchamp \& Childress 2013: 150-201).

Surrogatmoren kan oppleve en del plager og ubehag ved et svangerskap. Det er også betydelig risiko forbundet med å gjennomgå en graviditet. Så å få surrogatmor til å gjennomgå et svangerskap på vegne av andre kan i det minste betraktes som å øke risikoen for 
at hun kommer til skade. Det vil i så fall stride mot prinsippet om å ikke skade. På den annen side har ikke helsepersonell noen plikt til å advare kvinner mot å bli gravide på egen hånd eller hjelpe dem med å bli gravide under andre omstendigheter. Så hvorfor skulle det være annerledes med surrogati? Freeman argumenterer med at kvinner lenge har utsatt seg for helsemessige risikoer i forbindelse med svangerskap, enda mer i tidligere tider, før det kom god fødselshjelp (Freeman 1999 i Ramskold \& Posner 2013). Risikoen for skade er jo ikke større bare fordi barnet ikke er hennes eget.

Det er også verd å nevne, nok en gang, at det ikke bare er fysisk man kan skade noen. Det kan være en mental belastning å måtte gi fra seg et barn man har båret i ni måneder. Dessuten er det mange fordommer mot surrogati, og mange finner det uakseptabelt. Dette kan få konsekvenser for surrogatmoren med hensyn til både verdighet og selvrespekt. Dessuten kan det hende at familien og nærmiljøet ikke godtar at hun er surrogatmor med de sosiale følgene det kan få. Surrogati kan med andre ord skade surrogatmoren på flere nivå enn bare det fysiske.

Det er også et spørsmål om hvordan et potensielt barn som blir født gjennom surrogati, vil reagere på det i ettertid. I et samfunn som det norske, hvor opphav og arv har så mye å si for mange, vil det være mulig at barnet får et identitetsproblem som følge av at det kom til verden gjennom surrogati. Ifølge den norske bioteknologiloven er det ikke lov å være anonym sæddonor i Norge (Bioteknologinemda 2011). Dette er ikke forbudt i alle andre land, så dersom man benytter seg av utenlandske donorer eller surrogatmødre, er det ikke krav om at de skal være kjent for barnet. Det gjelder for eksempel i Danmark og USA (Bioteknologinemda 2010; American Pregnancy Association 2012). Studier har vist det kan ha negative psykososiale konsekvenser for barn ikke å vite hvordan de er unnfanget, det gjelder ved både adopsjon og donasjon (Bioteknologinemda 2011). Surrogati er enda så nytt at man ikke har forsket så mye på hvilke konsekvenser det vil få for barnets identitet på sikt, men det er likevel trolig at det vil være mange av de samme problemstillingene som ved adopsjon og donasjon.

Så lenge surrogati ikke er godtatt i Norge, er det en konflikt mellom de to landene om hvor barnet hører til. Man risikerer altså at lovgivningen straffer en uskyldig part, barnet, hvis man ikke har tydelige reguleringer fra Norge sin side. Det kan også være en belastning for de intenderte foreldrene at den norske stat ikke anerkjenner at barnet er deres.

\section{Rettferdighet og surrogati}

Hva som ansees som en rettferdig fordeling, avhenger av hvilke teorier om rettferdighet man forholder seg til. Disse teoriene er ikke praktiske instrumenter som peker ut handlingsalternativer for oss, men de representerer modeller for ulike hensyn som bør vektlegges når man forsøker å etterleve prinsippet om å sikre rettferdighet. I denne artikkelen henviser vi til tre teorier om rettferdighet for å belyse og drøfte etiske sider ved surrogati. Egalitore teorier legger vekt på lik tilgang til goder i livet. I libertarianske teorier handler det om både sosial og økonomisk frihet, og teorien fremmer rettferdige prosedyrer fremfor rettferdige utfall. Ifølge såkalte «capability»-teorier skal samfunnet beskytte individets kapasitet og frihet til å ha et godt liv. Prinsipper som er viktig i forbindelse med 
rettferdighet, er det å sikre like muligheter og å unngå diskriminering og utnyttelse (Beauchamp \& Childress 2013: 249-301).

I forbindelse med surrogati er særlig det å forhindre utnyttelse og det å sikre like muligheter relevant å diskutere fra et rettferdighetsperspektiv. Vi begynner med å se på utnyttelse. Ifølge forfatterne av «Principles of Biomedical Ethics» kan problemet med utnyttelse omhandle personer som er i en ugunstig situasjon, og som på grunn av fattigdom og andre samfunnsmessige strukturer mangler reelle alternativer. Dermed kan de føle seg tvunget eller presset til å godta tilbud som de ellers ikke ville akseptere, og de påtar seg en risiko de ville ha unngått under andre omstendigheter (Beauchamp \& Childress 2013: 249-301). Det er ingen tvil om at mange av de kvinnene som velger å bli surrogatmødre, er i en ugunstig situasjon, og det er nok mange som ikke har andre alternativer for å tjene penger. Samtidig vil det å gjennomgå et surrogatsvangerskap alltid innebære en viss risiko for komplikasjoner, både fysiske, mentale og sosiale. Kvinner i en slik situasjon vil kunne utnyttes av både klinikkene og familien til å bære risikoen for deres økonomiske gevinst. Men vi presiserer at dette trenger absolutt ikke gjelde alle.

I «capabilities»-teorien er et viktig tema å sikre rettigheter og unngå skade på sårbare grupper (Beauchamp \& Childress 2013: 249-301). Et motargument til dette finner vi i «Principles of Biomedical Ethics», hvor forfatterne skriver at det er fristende å ekskludere økonomisk vanskeligstilte grupper fra forskning, slik at de ikke skal bli utnyttet, men at dette er en urettferdig og paternalistisk form for diskriminering (Beauchamp \& Childress 2013: 249-301). Det samme kan sies om fattige indiske kvinner i forbindelse med surrogati. Å ekskludere dem bare på grunnlag av at de er en sårbar gruppe, er urettferdig og paternalistisk. Det er i strid med de egalitære teoriene om rettferdighet som legger stor vekt på like muligheter, og det kan ansees som urettferdig å frata de indiske kvinnene mulighetene til å tjene penger på surrogati. Et slikt syn vil også støttes av libertarianske teorier, som legger stor vekt på sosial og økonomisk frihet (Beauchamp \& Childress 2013: 249-301). Men selv om man godtar at man ikke kan ekskludere alle fattige indiske kvinner fra surrogati, må man likevel være oppmerksom på at det kan føre til utnyttelse.

I forbindelse med prinsippet om å fremme like muligheter for alle blir det også naturlig å tenke på om det å få barn gjennom surrogati er et alternativ som skal være tilgjengelig for alle. Surrogati er en kostbar prosess, og ikke alle har mulighet til å bruke så mye penger på å skaffe seg barn. Dermed kan surrogati ende opp med å bli et alternativ for en ressurssterk elite av barnløse, noe som kan føre til fordelingsurettferdighet blant barnløse. Man kan også argumentere med at like muligheter innebærer at alle burde ha muligheten til å få barn. I den indiske loven om reproduksjonsteknologi vi har skrevet om tidligere, står det at alle par har rett til å få barn. Dette er særlig viktig i India ettersom at barnløshet fører med seg mye stigma, i tillegg til at det er barna som tar vare på foreldrene når de er gamle (Government of India 2010). I den norske velferdsstaten, derimot, tilrettelegges det for at eldre i samfunnet kan bli tatt vare på uavhengig av om de har barn eller ikke. Mot denne bakgrunn er det ikke i en norsk kontekst opplagt at det å få hjelp til å få barn bør imøtekommes som en moralsk rett barnløse har.

De ulike partene i surrogatiprosessen stiller på svært ulikt grunnlag i en forhandlingssituasjon. Surrogatmødrene er i mange tilfeller fattige og lite utdannede. De er selvsten- 
dige oppdragstakere og forventes ofte å kunne forhandle frem egne vilkår. Det er de som skal bære byrdene og risikoen med prosessen. De intenderte foreldrene er som regel nokså ressurssterke, men de er også ofte i en sårbar situasjon. Ønsket om å få et barn er ofte veldig sterkt, og dermed er det en fare for at de kan presses til å godta ting de egentlig ikke er komfortable med. Klinikkene skal i prinsippet representere både surrogatmødrene og de intenderte foreldrene, men ettersom det er de intenderte foreldrene som er de betalende kundene, er det potensial for favorisering av dem fra klinikkens side (Deonandan et al. 2012). Klinikkene har mye å vinne økonomisk, mens de andre partene har mer å tape. Klinikkene står dermed i en maktposisjon. Det at de ulike partene stiller så ulikt i situasjonen, er bekymringsverdig fordi det gir rom for utnyttelse, både av surrogatmødre og av de intenderte foreldrene.

\section{Etiske spenninger i forbindelse med surrogati}

Surrogatidebatten er et godt eksempel på en debatt over et reelt etisk dilemma. Tungtveiende hensyn kommer i konflikt, og uansett hvordan man vrir og vender på problemstillingen, finnes det ingen opplagte løsninger uten etiske omkostninger. Spenningene oppstår fordi prinsippenes ulike verdigrunnlag kommer i konflikt, og fordi prinsipielle, idealistiske perspektiver av dilemmaet ikke sammenfaller med den reelle, ikke-idealiserte virkeligheten som politiske styringsmakter må forholde seg til.

Prinsippet om å respektere den enkeltes autonomi er svært relevant i spørsmålet om å tilrettelegge for surrogati. Autonomien kan begrenses både på individnivå, i henhold til enkeltindividenes interne og eksterne forutsetninger, og på populasjonsnivå, i henhold til samfunnsmessige reguleringer av ulike gruppers valgmuligheter. I Norge står individets rettigheter veldig sterkt, og man strekker seg langt for å hjelpe par med å få barn. Samtidig er Norge et regulert samfunn der individets frihet er begrenset, særlig i situasjoner der deres handlinger kan gi negative konsekvenser for andre. I denne sammenheng må man se på de intenderte foreldrenes ønske om å få barn opp mot om dette kan føre til utnyttelse av surrogatmoren. Som et rettferdighetssøkende samfunn kan vi ikke godta at norske pars ønsker om å få barn fører til at indiske kvinner blir utnyttet på noen måte. Samtidig kan man heller ikke utelukke at enkeltindivider, til tross for ugunstige livsvilkår, er i stand til å ta autonome avgjørelser knyttet til eget liv og helse. Det vil være generaliserende og diskriminerende å anta at alle indiske kvinner som tilbyr seg å være surrogatmor, blir utnyttet. Et forbud som regulerer surrogatmødre på gruppenivå, vil sånn sett kunne ramme enkeltindivider på urettferdig vis ved å frata henne en potensiell inntektskilde som også vil kunne styrke hennes sosiale status, og restrukturere nåværende sosioøkonomiske strukturer som er undertrykkende og skadelige i seg selv. Hvis dette blir reelle konsekvenser av et forbud, vil prinsippet om å respektere individers autonomi stå i konflikt med prinsippet om rettferdighet. I tillegg vil man kunne hevde at et slikt forbud på urettferdig vis begrenser Indias muligheter for økonomisk vekst og sysselsetting gjennom surrogatindustrien. I så fall vil den norske nasjonens etterfølgelse av prinsippet om ikke å skade (ved å forhindre utnyttelse) komme i konflikt med prinsippet om rettferdighet, ettersom 
man avviser en industri som har et potensial for å påvirke reelle økonomiske forskjeller mellom populasjoner og dermed underliggende, ikke-rettferdiggjorte, sosioøkonomiske ulikhetsstrukturer i India.

Prinsippet om å ikke skade kommer også i konflikt med velgjørenhetsprinsippet når dette relateres til barnløse og en tilrettelegging av deres mulighet til å få et etterlengtet barn. En kan argumentere for at barna er den parten som det er viktigst å ivareta fra samfunnets side, ettersom de ikke har anledning til å påvirke situasjonen selv. Derfor må man ta farene med at barna kan bli statsløse og få eventuelle påfølgende psykososiale senskader, på alvor.

Også innad i prinsippet om rettferdighet oppstår det spenninger i forbindelse med spørsmålet om hvorvidt surrogati bør tillates. I surrogatidebatten trekkes det analogier til prostitusjon, menneskehandel og salg av organer. Desperate mennesker kan gjøre desperate ting, og for mange er ønsket om å komme ut av fattigdom så stort at de er villige til å utsette seg selv for stor risiko. Skal samfunnet beskytte disse menneskene for risiko gjennom lovforbud? Det vil kunne være i tråd med «capabilities»-teorien dersom man legger større vekt på god helse enn på den økonomiske gevinsten kvinnene får. Det vil derimot stride mot libertarianske teorier fordi det innskrenker valgmulighetene til både de intenderte foreldrene, klinikken og kvinnen.

Politiske beslutninger om å regulere samfunnsforhold er ikke ansvarsfullt tatt om man ikke også har vurdert forventede empiriske konsekvenser av tiltakene. Freeman forespeiler oss et svarte marked dersom surrogati forbys (Freeman 1999 i Ramskold \& Posner 2013). Opplysninger om hvordan den virkelige verden fungerer, eller kan forventes å fungere, trumfer på sett og vis idealistiske forestillinger om hvordan den bør fungere når det kommer til ansvarlige politiske beslutninger. Dersom et forbud mot surrogati over landegrensene stimulerer til fremvekst av et uoversiktlig svart marked, er det samtidig en stor risiko for at det vil føre til enda dårligere forhold for de intenderte foreldrene, surrogatmødrene og barna enn i dag.

\section{Veien videre}

Hvordan skal man så forholde seg til spørsmålet om norske par bør få lov til å benytte seg av surrogati i India? Ramskold og Posner (2013) hevder at for å hindre utnyttende fertilitetsturisme er det nødvendig å tillate og regulere surrogati. Dersom man tillater surrogati, er det en sjanse for at det blir mer vanlig og mer godtatt i samfunnet. Da vil muligens belastningen på barn som er født gjennom surrogati, bli betydelig mindre, samtidig som man fjerner risikoen for at barnet blir statsløst. Ved å legalisere surrogati vil man kunne kreve en bedre regulering av prosessen til de enkelte parters behov. Partene i surrogatiprosessen stiller som regel på svært ulikt grunnlag. Ofte kan det være vanskelig for surrogatmoren å hevde sine rettigheter, så ved å legalisere surrogati kan man lovfeste surrogatmorens rettigheter, og det kan bli mulig å stille krav til at surrogatmoren er bedre informert om de risikoene surrogati innebærer både fysisk, mentalt og sosialt. Man kan også gjennom reguleringer sørge for at hun blir tatt godt vare på både fysisk og mentalt 
også etter svangerskapet. Videre kan det stilles krav om kontroll av klinikken, slik at de intenderte foreldrene kan være sikre på at prosessen foregår slik den blir beskrevet. Det kan også stilles krav til de intenderte foreldrene om skikkethet på samme måte som ved adopsjon. Samtidig kan det også være ulemper ved regulering. Hvis prosessene blir strengere regulert, er det en mulighet for at surrogatiprosessen kan bli mer kostbar, og dermed vil par med dårligere økonomi være ekskludert fra å benytte seg av denne tjenesten. Muligheten for å tilrettelegge for økonomisk velgjørenhet, og bedre regulering som igjen kan gjøre situasjonen bedre for de involverte partene, vil imidlertid overstyre dette rettferdighetshensynet om å sikre like muligheter til å benytte seg av surrogati.

Hvis Norge velger å åpne for surrogati i utlandet, vil det være etisk problematisk å ikke åpne dørene for det også nasjonalt. Siden kostnadsnivået i Norge er i det øvre sjiktet i verden, er det trolig at kvinner vil kreve så høy betaling for å være surrogatmor at det ikke vil være mange norske par/enslige som kan ta seg råd til å betale for tjenesten nasjonalt. Så i praksis kan en åpning for dette både internasjonalt og nasjonalt være mest på papiret, og de fleste vil nok likevel velge å dra til et land med lavere kostnadsnivå.

I hvilken grad skal den norske stat legge til rette for at de som ikke kan få barn på egen hånd, skal ha andre alternativ tilgjengelig? Man har per i dag tilbud som adopsjon, IVFbehandling og sæddonasjon med kjent donor. Skal man også åpne opp for surrogati? Hvis Norge velger å gjøre surrogati lovlig, er det naturligvis vanskelig å forutsi hvilke konkrete konsekvenser det vil kunne få på sikt, og det blir vanskelig å gå tilbake på vedtaket i etterkant. Det er derfor viktig at konsekvensene av å tillate surrogati blir utredet etter beste evne.

\section{Konklusjon}

Det er mange argumenter både for og mot å tillate norske par å benytte seg av surrogati i India. De viktigste argumentene mot er at det kan føre til utnyttelse av indiske kvinner, og at barnet kan bli skadelidende i form av statsløshet eller psykososiale senskader. I tillegg kan det vise seg at norske pars ønsker om å få barn blir realisert på bekostning av indiske kvinners helse, og samfunnet har et ansvar for å beskytte mennesker mot skade.

Argumenter for er at man hjelper barnløse par med å få barn, og man tar indiske kvinners autonomi på alvor og gir henne en potensiell inntektskilde. Spørsmålet er om ikkeskade-prinsippet bør trumfe prinsippet om å respektere surrogatmødrenes potensielle autonome valg og prinsippet om å gjøre godt for surrogatmødrene ved å gi dem en mulig inntektskilde. Aksepterer man at prinsippet om ikke å skade må veie tyngst, må man ta stilling til hvorvidt ikke-skade-prinsippet faktisk kan realiseres i den virkelige, ikke-ideelle verden dersom et svart marked oppstår.

Ved å legalisere surrogati vil man også kunne sikre en bedre regulering av prosessen og dermed fjerne en del av de problemene man ser i dag. Blant annet vil ikke barnet lenger kunne bli statsløst. Det kan bli vanligere og mer anerkjent å bli født gjennom surrogati, og dermed vil det kunne bli mindre mentalt belastende for barna. Like viktig vil det være at man også lettere kan forhindre at kvinner blir utnyttet: Ved å legalisere surrogati vil 
man ved målrettet bruk av reguleringer kunne minske risiko for å skade de involverte partene. Surrogati har allerede blitt en stor industri, og ved å tillate det i kontrollerte former reduseres risikoen for svarte markeder som kynisk utnytter kontraktens svakeste parter. Det finnes ingen omkostningsfrie løsninger på etiske dilemma. Analysen vi har foretatt, gir imidlertid visse holdepunkter for at en åpen og godt regulert prosess vil kunne redusere skadeomfanget av surrogatipraksisen slik den utspiller seg i en virkelig og ikke-ideell verden. Hvis det innføres et forbud, står vi uten virkemidler til å kunne konstruktivt påvirke og balansere denne praksisen med hensyn til relevante prinsipper om autonomi, ikke-skade, velgjørenhet og rettferdighet.

\section{Referanser}

American Pregnancy Association (2012) Donor Insemination. Lastet ned 10. september 2013 fra: http://americanpregnancy.org/infertility/donorinsemination.html

Barne- likestillings- og inkluderingsdepartementet (1981) Lov om barn og foreldre (barnelova). Oslo: Barne- likestillings- og inkluderingsdepartementet. Lastet ned 15. mars 2013 fra: http:// www.lovdata.no/dokument/NL/lov/1981-04-08-7

Barne- likestillings- og inkluderingsdepartementet (1986) Lov om adopsjon (adopsjonsloven). Oslo: Barne- likestillings- og inkluderingsdepartementet. Lastet ned 27. mars 2013 fra: http:// www.lovdata.no/dokument/NL/lov/1986-02-28-8

Beauchamp, T.L. \& Childress, J.F. (2013) Principles of Biomedical Ethics. Oxford \& New York: Oxford University Press.

Bioteknologinemnda (2010) Assistert befruktning. Oslo: Bioteknologinemnda. Lastet ned 10. september 2013 fra http://www.bion.no/temaer/assistert-befruktning/regelverk/

Bioteknologinemnda (2011) Bioteknologinemdas uttalse om eggdonasjon. Lastet ned 17. april 2013 fra http://www.bion.no/filarkiv/2011/11/Bioteknologinemndas-uttalelse-om-eggdonasjon.pdf

Clouser, K. \& Gert, B. (1990) A critique of principlism. Journal of Medicine and Philosphy, 15, s. 219-236.

Deonandan, R., Green, S. \& Beinum, A.V. (2012) Ethical concerns for maternal surrogacy and reproductive tourism. Journal of Medical Ethics, 38, s. 742-745.

Dommerud, T. (2013) 37 barn av surrogatmor stebarnsadoptert i Norge i 2012. Aftenposten, 3. april. Lastet ned 4. april 2013 fra http://www.aftenposten.no/helse/37-barn-av-surrogatmorstebarnsadoptert-i-Norge-i-2012-7163700.html

Government of India (2010) The assisted reproductive technologies (regulation) bill - 2010. Lastet ned 5. mars 2013 fra http://www.nrk.no/contentfile/file/1.7558871!Surrogati i India.pdf

Government of India (2013) Visit of foreigners for surrogacy. Lastet ned 3. april 2013 fra http:// mha1.nic.in/par2013/par2013-pdfs/ls-190313/3491.pdf

Hammer, J.L. (2012) Barnløse par lever kortere. Lastet ned 12. april 2013 fra http://www.forskning.no/artikler/2012/desember/341642

Løvaas, L. (1998) Psykisk belastning ved ufrivillig barnløshet. Lastet ned 11. september 2013 fra http://www.onskebarn.no/- Ufrivillig barnl\%F8shet/Artikler om ufrivillig barnl\%F8shet/ ?article_id=101

Nesheim, B.-I. (2009) Ufrivillig barnløshet. Lastet ned 12. april 2013 fra http://smn.snl.no/ ufrivillig_barnløshet

Newlife India (2012) Contract between Agency and Surrogate Mother. Lastet ned 16. mars 2013 fra http://www.newlifeindia.com/Contracts 
Prestegård, S. (2013) Vet ikke tallet på surrogatbarn. Dagsavisen, 3. april. Lastet ned 4. april 2013 fra http://www.dagsavisen.no/samfunn/vet-ikke-tallet-pa-surrogatbarn/

Ramskold, L.A.H. \& Posner, M.P. (2013) Commercial surrogacy: How provisions of monetary remuneration and powers of international law can prevent exploitation of gestational surrogates. Journal of Medical Ethics, 39, s. 397-402.

Regjeringen (2013) Surrogati. Oslo: Regjeringen. Lastet ned 10. mai 2013 fra http://www.regjeringen.no/nb/dep/bld/aktuelt/nyheter/2011/surrogati.html?id=660199

Shetty, P. (2012) India's unregulated surrogacy industry. The Lancet, 380 (9854), s. 1633-1634. Lastet ned 12. september 2013 fra http://www.thelancet.com/journals/lancet/article/PIIS01406736(12)61933-3/fulltext

Statistisk sentralbyrå (2012) Foreldrenes gjennomsnittsalder ved fødsler. 1946-2011. Lastet ned 12. april 2013 fra http://ssb.no/a/kortnavn/fodte/tab-2012-04-11-04.html

Store Norske Leksikon (2012a) India. Lastet ned 12. april 2013 fra http://snl.no/India

Store Norske Leksikon (2012b) Skole og utdanning i India. Lastet ned 27. mars 2013 fra http:// snl.no/Skole_og_utdanning_i_India

Sundby, J. (2010) Hva er en mor? Samtiden, 4, s. 90-105.

Syse, A. (2012) Surrogati og foreldreskap. Tidsskrift for Den norske legeforening, 132, s. 983-984.

Taylor, R. 2011. India: Women Exploited in Surrogacy Pregnancy Contracts. Lastet ned 11. september 2013 fra http://www.lifenews.com/2011/09/08/india-women-exploited-in-surrogacy-pregnancy-contracts/ 